\title{
SEASONAL DISTRIBUTION AND EVOLVING FORMS OF MULTIPLE SCLEROSIS PATIENTS DIAGNOSED FROM APRIL 2004 TO NOVEMBER 2007
}

\author{
Hermes Fundora-Hernández, Alberto J. Dorta-Contreras, Maray Socias-López, \\ Silvana Fraga-Santana, Silvia Nicté Villatoro-Rodríguez, Bárbara Padilla-Docal, \\ Elena Noris-García, Raisa Bu-Coifiu-Fanego, Marlén González-Hernández
}

\begin{abstract}
Background: Multiple sclerosis (MS) was first reported in Cuba in 1965. The most frequent appearance is observed in the first six months of the year. Objective: To determine the seasonal distribution and evolving forms of MS patients diagnosed with the disease between April 2004 and November 2007. Method: Twentyone patients with suspected MS and 42 outbreaks were studied. Patients were classified according to Lublin and Revingold's criteria for clinical forms and according to McDonald. Results: Most patients were classified in outbreak and remission and only two patients classified as primary-progressive multiple sclerosis. The higher number of outbreaks occurred in the first two quarters of the year. Conclusion: It is recommended to study further weather variables that may be related to the emergence of these outbreaks in our environment.
\end{abstract}

KEY WORDS: multiple sclerosis, epidemiology, environmental factors.

Distribución estacional y formas evolutivas de esclerosis múltiple en pacientes diagnosticados entre Abril del 2004 y Noviembre del 2007

\begin{abstract}
Resumen - Introducción: La esclerosis múltiple (EM) fue reportada en Cuba por primera vez en 1965. Se ha venido observando la aparición más frecuente en los primeros seis meses del año. Objetivo: Determinar la distribución estacional y formas evolutivas de EM en pacientes con diagnóstico de esta enfermedad entre abril 2004 y noviembre 2007. Método: Se estudiaron 21 pacientes con sospecha de EM y un total de 42 brotes. Los pacientes fueron clasificados según los criterios de Lublin y Revingold para las formas evolutivas y según los criterios de McDonald. Resultados: Solo dos pacientes clasificaron en la forma evolutiva progresiva primaria; los primeros dos trimestres del año fueron los de mayor número de brotes. Conclusión: Se recomienda profundizar en las variables climatológicas que pudieran tener vínculo con la aparición de estos brotes en nuestro medio.
\end{abstract}

PALABRAS-CLAVES: esclerosis múltiple, epidemiología, factores ambientales.

First anatomopathological descriptions of multiple sclerosis (MS) were done by Cruveilhier' and Carswell', however, Charcot in 1868, provided the first detailed description of the clinical and evolutive aspects of the disease and stated the concept of plate sclerosis. English authors called it disseminated sclerosis due to the spread of lesions in the central nervous system (CNS), afterwards North American authors called it multiple sclerosis (MS) and it is the most used name.
The relation among latitude, climate genetics and the prevalence of MS is well known ${ }^{2-7}$. The disease is more frequent in geographic regions with cold winters, mild summers and rainfalls evenly spread throughout the whole year ${ }^{3}$.

However, some seasonality related with the outbreaks of MS has been empirically observed in Cuba.

This paper aims at determining seasonal distribution and evolving forms of MS patients diagnosed with the disease from April 2004 to November 2007.

\footnotetext{
Laboratorio Central de Líquido Cefalorraquídeo (LABCEL), Facultad de Ciencias Médicas “Dr. Miguel Enríquez”, Instituto Superior de Ciencias Médicas de La Habana.

Received 6 June 2008, received in final form 25 March 2009. Accepted 30 May 2009.

Dr. Hermes Fundora-Hernández - Laboratorio Central de Liquido Cefalorraquídeo (LABCEL) / Facultad de Ciencias Médicas "Dr. Miguel Enríquez" / Instituto Superior de Ciencias Médicas de La Habana - Apartado 10049 - CP 11000 Ciudad Habana - Cuba. E-mail: hermes.fundora@infomed.sld.cu
} 


\section{METHOD}

Twenty-one patients with clinical suspicion of MS were studied. They were classified according to Lublin and Revingold and Mc Donald's criteria ${ }^{8,9}$.

A sample of serum and cerebrospinal fluid (CSF) was collected from each patient. Albumin and IgG of both fluids were quantified by simple radial immunodiffusion in NOR and LC Partigen plates from Dade Behring (Marburg). Albumin and IgG concentrations were turned into quotients $\mathrm{CSF} /$ serum and were plotted in the reibergrams according to Wormek's CSF Laboratory program version 3.0.

The clinical records of patients specifying the dates of outbreaks, how they evolved and the most important clinical features as well as the categorization of the disease were checked.

\section{RESULTS}

The $90.5 \%$ of the patients was classified as relapsingremitting MS, according to Lublin and Revingold's criteria.

The frequency of outbreaks of MS was distributed in quarters. These results are shown in Figure.

\section{DISCUSSION}

Relapsing-remitting multiple sclerosis and primaryprogressive MS were the evolving forms in our sample, with predominance of the former. This result matches the literature, where it is also the most common form of presentation ${ }^{10}$. Cases of secondary-progressive multiple sclerosis and progressive remitting multiple sclerosis were not found.

According to the epidemiology of MS, there may be a relation between the disease and any environmental factor. It seems to be that, some environmental factor acts during childhood in genetically predisposed individuals. After years of latency, this same factor seems either to start the disease or to contribute to its causes. Many authors have considered the infection by certain viruses as the candidate. Despite the findings of intrathecal response to a large list of viruses, neither the viral genetic material has been isolated in active MS plates with a well established etiological relation, nor there is a viral model of the disease ${ }^{9-16}$.

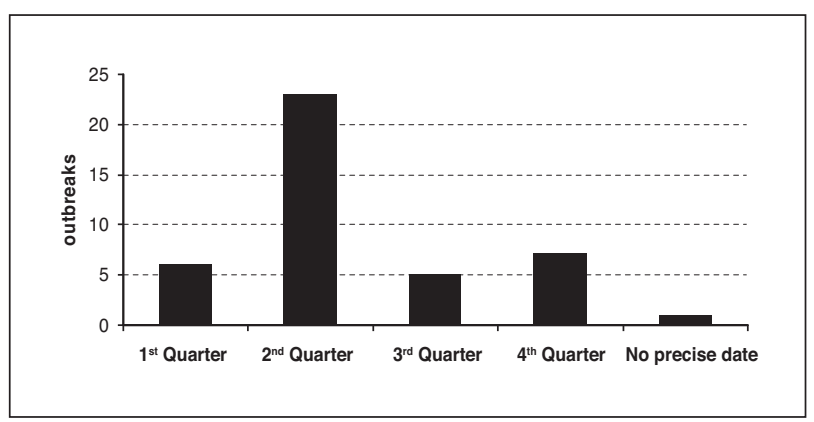

Figure. Frequency of MS outbreaks per quarters. Comparison of proportions, $p<0.01$
A viral infection might be the initial event in the genesis of MS and some secondary factor might act during life activating the disease or causing the outbreaks.

Based on prevalence, three risk areas can be considered according to Kutzke ${ }^{17,18}$.

High risk area: when prevalence is higher than or equal to 30 cases per 100000 inhabitants. Between $65^{\circ}$ and $43^{\circ}$ north latitude, northern Europe, USA and Canada and between $33^{\circ}$ and $44^{\circ}$ south latitude (Australia and New Zealand). Medium risk area: when prevalence is $5-29$ cases per 10000 inhabitants, southeast USA, south Europe and southern Australia. Low risk area: when the prevalence is less than 5 cases per 10000 inhabitants, Asia, Latin America, Africa and regions close to the equator. Cuba is included in this the area.

The estimated prevalence of clinically definite MS in Cuba was 4.42 cases per 100000 inhabitants using as source the case registers of all provinces and of the Association of Multiple Sclerosis patients in Cuba ${ }^{19}$.

According to our the results, outbreaks occur more frequently in the first two quarters of the year and their frequency is particularly higher in the second quarter that corresponds to April to June.

April, in our country, is the last month of the dry season (winter) and it is considered to be a transition month from winter to summer. Lately, this month have had a tendency to high temperatures and a variable thermal oscillation. This month marks the beginning of the quarter where outbreaks of MS are more frequent, and it might be related with the features mentioned above. From January to March there have been changes in the thermal regime with a greater range of variations, and El Niño Southern Oscillation event has been considered their cause ${ }^{20-22}$.

Many studies found a relation between outbreaks emergence with different weather variables and seasons. When conducting analyses of the seasonal outbreaks of MS, the results have been contradictory depending on the geographical locations where these studies have been performed. These contradictory data make difficult the establishment of a seasonal or month incidence of MS outbreaks that may be applicable everywhere ${ }^{23-27}$.

It has been reported that there are certain climate parameters in some seasons that favor MS outbreaks in patients suffering from this disease ${ }^{26,27}$. Other studies have stated that under certain weather conditions the start of MS patients occurs regardless of their clinical presentation ${ }^{28}$.

Studies carried out by Partridge in Spain, where immigrants were enrolled, found out that latitude susceptibility to suffer this disease is particularly special during childhood $^{29}$. Van der Mei and colleagues identified that exposure to sunlight, mainly in winter, between the ages of 6 and 15 years, is related to a decrease in the risk of $\mathrm{MS}^{23}$.

According to Wüthrich ${ }^{3}$, the number of outbreaks in- 
creases in winter and spring in Switzerland. A non significant tendency to increase during the summer, mainly in July, has been observed in England according to Shapira ${ }^{4}$. An increase of outbreak incidence from April to June in Galicia, Spain has been described by Abella-Corral ${ }^{14}$ and this finding coincides with what we found in our study.

Aver, Shumman and Kumpfel have found related seasonal variations with the appearance of lesions by nuclear magnetic resonance (NMR). They found that the number and activity of lesions in NMR were significantly higher in the first half of the year than in the second on $\mathrm{e}^{26}$. On the other hand, Rovaris and colleagues found that more active lesions appeared in the NMR in March and less in December, though this results were not statistically significant ${ }^{27}$. An analysis of MS seasonal outbreaks in Palencia, Spain showed a non- statistically significant trend towards the diminishing of outbreaks in the summer ${ }^{28}$.

There are also data from USA were more outbreaks are observed from July to October in Ohio and in spring in Minnesota ${ }^{8}$. A study conducted in Arizona showed a non-significant trend to increase relapses in spring and at the beginning of summer ${ }^{5}$. O'Reilly et al. carried out a study in the west of Ireland. As a result they established the relation between the outbreak frequency and concrete weather variables. Correlation between them was not observed, however there was an increase in the duration of the symptoms of the outbreak in periods of peak temperature and solar radiation, or lower relative humidity and volume of rainfall ${ }^{27}$.

In summary, there is certain seasonality in the behavior of the outbreaks in our country. A higher number of patients will allow us to reassert this first approximation of our observations. It would be interesting to relate the season with various climatic variables and their relation to viral infections circulating in these months.

\section{REFERENCES}

1. Cruveilher J. Anatomie pathologique du corps humain: descriptions avec figures lithographiees et colories des diverses alterations morbides dont le corps humain est suceptible. Paris: JB Baillière, 1841.

2. Craswell R. Pathological anatomy: illustrations of elementary form of disease. London: Orne, Brown, Green and Longman; 1838.

3. Acheson ED, CA Bachrach CA, Wright FM. Some comments on the relationship of the distribution of multiple sclerosis to latitude, solar radiation and other variables. Act Neurol Scand 1960;35:132-147.

4. Laborde JM, Dando WA, Teetzen ML. Climate, diffused solar radiation and multiple sclerosis. Soc Sci Med 1988;27:231-238.

5. Wüthrich R, Reider HP. The seasonal incidence of multiple sclerosis in Switzerland. Eur Neurol 1970;3:257-264.
6. Bamford CR, Sibley WA, Thies C. Seasonal variation in multiple sclerosis exacerbations in Arizona. Neurology 1983;33:697-701.

7. Fernández O. Factores genéticos y ambientales en la esclerosis múltiple. Rev Neurol 2000;30:964-967.

8. Lublin FD, Reingold SC. Defining the clinical course of multiple sclerosis: results of an international survey. National Multiple Sclerosis Society (USA) Advisory Committee on Clinical Trials of New Agents in Multiple Sclerosis. Neurology 1996;46:907-911.

9. McDonald WI, Compston A, Edan G, et al. Recommended diagnostic criteria for multiple sclerosis: guidelines from the International Panel on the diagnosis of multiple sclerosis. Ann Neurol 2001;50:121-127.

10. Kantarci OH, Weinshenker BG. Natural history of multiple sclerosis. Neurol Clin 2005;23:17-38.

11. Arnadottir $\mathrm{T}$, Reunanen $\mathrm{M}$, Salmi A. Intrathecal synthesis of virus antibodies in multiple sclerosis patients. Infect Immunity 1982;38:399-407.

12. Challoner PB, Smith KT, Parker JD, et al. Plaque-associated expression of human herpesvirus 6 in multiple sclerosis. Proc Natl Acad Sci 1995;92:7440-7444.

13. Johnson RT. The virology of demyelinating diseases. Ann Neurol 1994; 36:54-60.

14. Johnson RT. Viral infections of the nervous system. Philadelphia: Lippincott-Raven, 1998.

15. Scarisbrick IA, Rodriguez M. Hit-Hit and hit-Run: viruses in the playing field of multiple sclerosis. Curr Neurol Neurosci Rep 2003;3:265-271.

16. Lassmann H, Bruck W, Lucchinetti CF. The immunopathology of multiple sclerosis: an overview. Brain Pathol 2007;17:210-218.

17. Levin LI, Munger KL, Rubertone MV. Temporal relationship between elevation of Epstein Barr virus antibody titers and initial onset of neurological symptoms in multiple sclerosis. JAMA 2005;293:2496-2500.

18. Kurtzke JF. MS epidemiology World Wide. One view of current status. Acta Neurol Scand 1995;161:223-233.

19. Martinez-Sobrepera HJ, Cabrera-Gómez JA, Tuero-Iglesias A. Factores exógenos en la etiología de la esclerosis múltiple en Cuba. Estudio de casos y controles. Rev Neurol 2001;33:931:936.

20. Ortiz Bultó PL, Rivero A, Antonio Pérez C, Pérez A, González C. Boletín epidemiológico. BOL IPK 2007;16:393-394.

21. Ortiz Bultó PL, Pérez A, Rivero A, Díaz M. Boletín Epidemiológico. BOL IPK 2007;17:97-98.

22. Van der Mei IAF, Ponsonby AL, Blizzard L, Dwyer T. Regional variation in multiple sclerosis prevalence in Australia and its association with ambient ultraviolet radiation. Neuroepidemiology 2001;20:168-174.

23. Shapira K. The seasonal incidence of onset and exacerbations in multiple sclerosis. J Neurol Neurosurg Psychiatry 1959;22:285-286.

24. Abella-Corral J, Prieto JM, Dapena-Bolaño D, Iglesias-Gómez S, NoyaGarcía M, Lema M. Variaciones estacionales de los brotes en pacientes con esclerosis múltiple. Rev Neurol 2005;40:394-396.

25. O'Reilly MAR, O'Reilly PMR. Temporal influences on relapses of multiple sclerosis. Eur Neurol 1991;31:391-395.

26. Aver DP, Schumann EM, Kumpfel T. Seasonal fluctuations of gadolinium-enhancing magnetic resonance imaging lesions in multiple sclerosis. Ann Neurol 2000;47:276-277.

27. Rovaris M, Corni G, Sormani MP. Effects of seasons on magnetic resonance imaging-seasonal disease activity in patients with multiple sclerosis. Ann Neurol 2001;49:415-416.

28. Guerrero Peral AL, Carrasco-Cavia E, Díaz Gonzáles S, Fernández MJ, Martín Polo JM, Bueno Rodríguez V. Análisis estacional de brotes de esclerosis múltiple y su relación con diferentes variables climatológicas. Rev Neurol 2005;41:446-448.

29. Ziegler LH. Multiple sclerosis: clinical review and follow-up study. Minn Med 1989;12:778-783. 